\title{
Geoconservation and geodiversity for sustainable development in Madagascar
}

\author{
Tsilavo Raharimahefa
}

\begin{abstract}
Madagascar is well known for its unique and rare natural beauty, and it is one of the biodiversity hotspots for conservation priorities. Many efforts have been made for the protection of biodiversity, yet initiatives towards the conservation of geodiversity are often neglected. Geoconservation refers to the conservation of geological diversity or geodiversity, and it is often applied to a specific location, known as a geosite, where important earth features (geological, paleontological, geomorphological, hydrological and pedological) are protected, preserved and managed. Madagascar is very rich in natural resources and has many spectacular geological features, such as the beautiful gorges and canyons of Isalo, Tsingy de Bemaraha, Ankarana caves, hot springs and volcanic lakes of Itasy, all of which should be conserved and protected by local authorities, the private sector and local communities. Such initiatives can not only help to maintain and protect geological sites of particular importance, but also contribute to sustainable economic development. This essay aims to introduce geoconservation and sustainability in Madagascar, and to increase public knowledge and awareness of geodiversity and its conservation. The creation of geological tourism sites or geoparks is undoubtedly one of the most important steps to promote the conservation of geosites, and the promotion of earth science education should help expand and consolidate their protection.
\end{abstract}

\section{RÉSUMÉ}

Madagascar est renommée pour la beauté exceptionnelle de sa nature qui est unique. L'île est classée parmi les sites stratégiques nécessitant la mise en place de politiques de conservation de la biodiversité. Malgré les efforts déployés par les protecteurs de la nature au cours des dernières années pour la conservation des écosystèmes, la géoconservation demeure un nouveau concept de conservation qui est méconnu par la plupart des Malgaches. La géoconservation se réfère à la conservation de la diversité géologique ou géodiversité, qui s'applique généralement à un endroit spécifique désigné en tant que géosite, dans lequel on reconnait des éléments et des dispositifs géologiques importants qui méritent d'être protégés, préservés et gérés comme par exemple dans les domaines de la paléontologie, la géomorphologie, I'hydrologie et la pédologie. La géodiversité de Madagascar compte parmi les plus spectaculaires au monde, allant des rares gisements de minéraux à des
Department of Geology, University of Regina

3737 Wascana Parkway

Regina, Saskatchewan, S4S OA2, Canada

E-mail: raharimt@uregina.ca

paysages et des reliefs spectaculaires, en passant par de belles plages et des grottes qui sont autant de richesses qui pourraient être classées en tant que patrimoine géologique mondial. Face à la dégradation rapide de la géodiversité à Madagascar, il est urgent d'adopter une politique efficace de géoconservation de nombreux sites au profit de la population locale, qui devra aussi permettre de donner un coup de pouce au progrès vers le développement durable du pays.

\section{INTRODUCTION}

In the developing world economic growth depends largely on natural resources, and Madagascar is no exception. Madagascar, the world's fourth largest island, lies in the Indian Ocean approximately $400 \mathrm{~km}$ off the southeast coast of Africa and is well known for its unique and rare natural beauty (Ganzhorn et al. 2001, Goodman and Benstead 2003, Mittermeier et al. 2004). In Madagascar, nature conservation has been understood as biodiversity conservation (Myers et al. 2000, Rogers et al. 2010), despite the fact that the natural environment includes both biodiversity and geodiversity; both are equally important. Very little, if any, appears to have been done or said about the conservation of geological features and landforms in Madagascar. In fact, because of the strong focus on biodiversity, the importance of geodiversity has been 'pushed aside'. However, geology is a fundamental part of nature and much of the surface biodiversity relies on the underlying soil and rock. In this sense the variety of non-living nature, 'geodiversity', which consists of a wide range of processes, environments and evolution, strongly supports the variety and robustness of biodiversity. As such, geodiversity should be considered carefully for successful nature conservation to be achieved (Semeniuk 1997).

In many developing countries where millions of people are still living in poverty, governments often integrate or try to adopt the principles of sustainable development as a new paradigm for development and poverty eradication. Since most of the population are uneducated or under-educated, the developing world is forced to depend largely on natural capital such as the Earth's resources (e.g., water, land, minerals, oil) and biodiversity. Sustainable development has been defined as "development that meets the needs of the present without compromising the ability of future generations to meet their own needs" (World Commission on Environment and Development 1987) and it includes safeguarding and managing natural systems for future 
generations. Over the last decade, Madagascar has increased its knowledge and awareness of conservation. However, appropriate management strategies are still needed to reflect 'Malagasy' cultural philosophy and to ensure the maximum survival of wildlife, landscapes and landforms. Given the limited work and cooperation between current biodiversity conservationists and Earth scientists, it is important to integrate and bond wildlife and geological conservation, for instance, by proposing geoconservation in protected areas that are already recognized by local authorities and the people who live and work in such areas. Madagascar has numerous protected areas (Figure 1) managed by the Malagasy government through associations or by private and non-governmental organizations (Jenkins 1990, Madagascar National Parks 2011). Madagascar National Parks (formerly known as ANGAP or Association Nationale pour la Gestion des Aires Protégées) manages 48 protected areas, which include 6 Strict Nature Reserves, 19 National Parks and 23 Special Reserves (Madagascar National Parks 2011).

Earth resources help to fill many human needs which, through time, have become greater. They are used in industry as raw materials (e.g., iron, nickel, chromite, copper) (Figure 2), in construction (e.g., granite, aggregates), as energy sources (e.g., coal, oil) and in making products ranging from women's make-up to home decorations. Madagascar has diverse Earth resources ranging from the extremely rare (e.g., gemstones, landforms like the tsingy) to the abundant (e.g., laterite, rivers) upon which biodiversity is linked. Because Earth resources are non-renewable and are limited, they must be used wisely and their conservation should be included in any natural conservation policy. The map in Figure 2 shows the distribution of a few

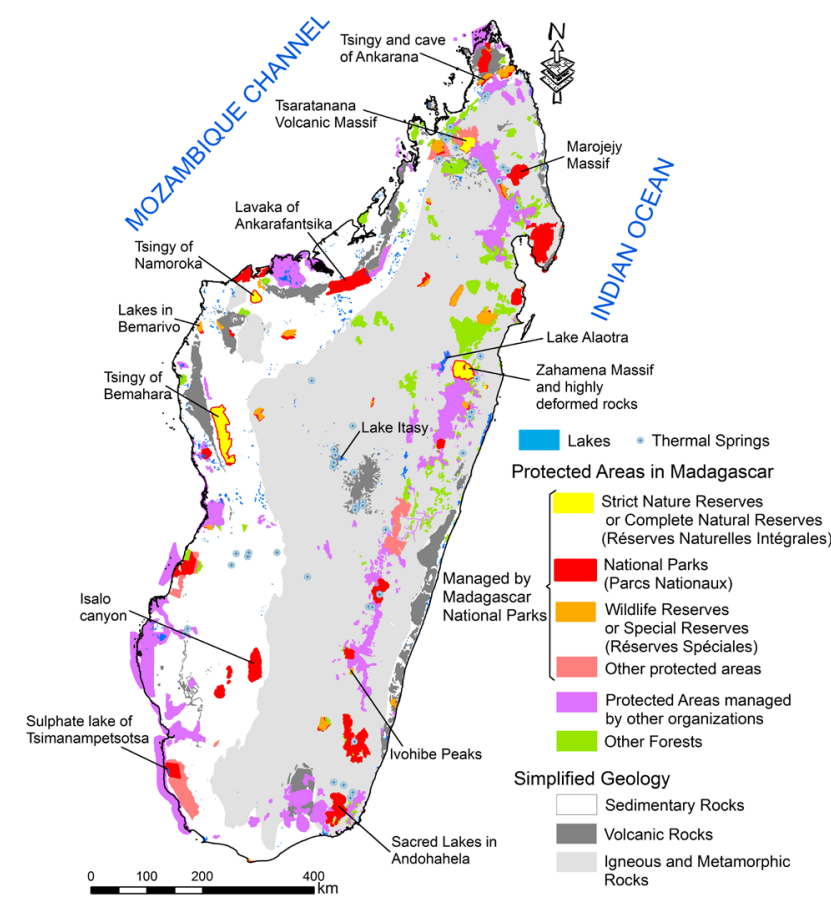

FIGURE 1. Extent and distribution of Protected Areas overlaying a very simplified geological map with lakes and thermal springs locations. The potential areas for geoconservation are labelled; these areas are considered to be at risk and need an immediate attention. Compiled from Foiben-Taosarintanin ${ }^{i}$ Madagascar BD500 (1998) and BD 200 (2001), Système des Aires Protégées de Madagascar data (2011), and Madagascar National Parks (2011). of Madagascar's mineral resources, fossils and fossil-fuel; these may or may not be included in protected areas.

This article is written to initiate and to increase public awareness of geoconservation and geodiversity in Madagascar, and to give background information on geoconservation, geodiversity and geosites, and why they are important. Furthermore, the paper describes some of the critical threats to Madagascar's geodiversity and illustrates the steps leading up to their conservation. It is our hope to develop geoconservation in Madagascar and take action to conserve significant, unique and rare geodiversity in order for it to contribute to the sustainable development of the country.

\section{GEOCONSERVATION, GEODIVERSITY AND GEO- SITES}

The meaning of the word 'geoconservation' might be seen as self-explanatory, however, several definitions do exist (Sharples 1995, 2002, Prosser 2002, Gray 2004). Geoconservation was defined as the conservation of geodiversity for its intrinsic, ecological and (geo)heritage values (Sharples 1995). More recently, the conservation of Earth features (geodiversity), such as geological features (bedrock, minerals, fossils), geomorphological features (landscapes, landforms), hydrological features (rivers, lakes) and pedological features (soil), and the maintenance of natural rates and magnitudes of change in those features and processes are defined as geoconservation (Sharples 2002). Geoconservation was also defined as the "protection and management of geological sites, areas and specimens for scientific research, education and training, where appropriate, popularization of the Earth's history for a wider public and promotion of

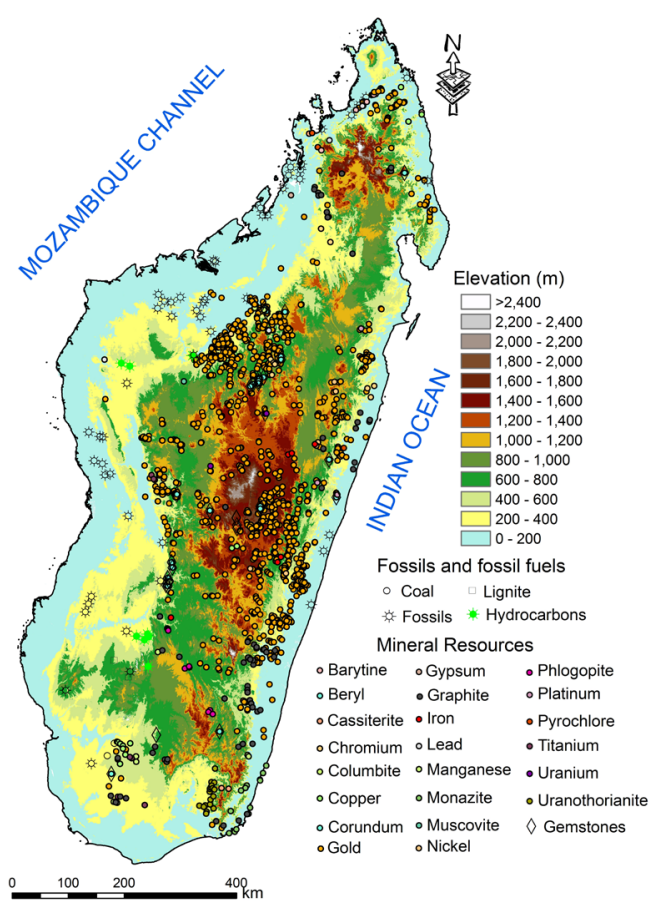

FIGURE 2. Digital Elevation Model of Madagascar computed from Shuttle Radar Topography Mission (SRTM) data showing the topography of the island, together with location of selected mineral resource commodities. Data compiled from Lacroix (1921-1923), Besairie $(1964,1968)$, Peters et al. (2003), Base de Données pour la Gouvemance des Resources Minérales (2005) and BGS-USGS-GLW (2008). 
good conservation practice" (ProGeo 2011). Generally speaking, it can be defined as the intent to conserve, monitor and enhance geological and geomorphological features, processes, sites and specimens (Burek and Prosser 2008).

Areas with specific and significant Earth features are called 'geosites' (geological sites), which may vary in size from a square meter to thousands of square kilometers, and can be very sensitive to human activities. Due to the natural diversity of geological, paleontological, hydrological, geomorphological and soil features, the term 'geodiversity' was introduced by a variety of authors including Sharples (1993), Dixon (1995), Kiernan (1997) and Osborne (2000), and includes their assemblages, properties, relationships, interpretations and systems (Gray 2004). When a geosite is promoted for tourism purposes (geotourism), it becomes a 'geopark'. Geological heritage or 'geoheritage' defines an important geosite that is considered to be of educational, scientific, research, recreational, aesthetic or inspirational value to humans (Legge and King 1992) and need conservation (Osborne 2000).

\section{GEOCONSERVATION AND GEODIVERSITY IN MADAGASCAR}

In Madagascar, geoconservation is still in its preliminary stages and it can be considered as a new concept to local authorities and the public. Public awareness of geoconservation depends largely on the educational background of the public. The successful practice of geoconservation will also depend on legislative, political and administrative support from local government. Madagascar's economy is still struggling (BTI 2012) and crippled by the political crisis, and funding and support from international and non-governmental organizations are therefore necessary and unavoidable.

The main island of Madagascar is $587,041 \mathrm{~km}^{2}$, running $1,577 \mathrm{~km}$ from north to south, $600 \mathrm{~km}$ from east to west and containing an area of $0.63 \times 10^{6} \mathrm{~km}^{2}$ of continental crust. Two thirds of the island is underlain by deformed and metamorphosed Precambrian crystalline basement rocks ( $>540$ Million-years), with the western part covered by a Phanerozoic sedimentary sequence (Devonian-Quaternary) and minor recent volcanic formations (Cretaceous-Quaternary), which have also intruded the central and southeastern parts of the island (Figure 1) (Besairie 1964, 1968). Madagascar was broken up from Gondwana in two distinctive stages, it separated from East Africa 160 million years ago, and broke away from India and the Seychelles between 90-66 million years ago (de Wit 2003, Yatheesh et al. 2006).

Madagascar has a remarkably rich geodiversity that includes exceptional landforms (karst peaks and needles, caves, bays) (Guilcher 1965, Vogt 1965, Duflos 1966, Wilson 1990); rare minerals (betafite, behierite, manandonite) (Lacroix 1921-1923, Behier 1960, Hogarth 1977, Ranorosoa et al. 1989); outstanding gemstones (emerald, ruby, sapphire) (Schwarz and Henn 1992, Rakotondrazafy et al. 2008); considerable industrial non-metallic and metallic ore-deposits (gold, copper, nickel, ilmenite) (Besairie 1964, 1968, BGS-USGS-GLW 2008, OMNIS 2012); fossils (dinosaurs, ammonites, petrified wood) (Boule and Thevenin 1906, Collignon 1962); spectacular structures (canyons, folds and faults) (Guilcher 1965, Arthaud et al. 1990); distinctive hydrological features such as deltas (e.g., Betsiboka delta), fast-flowing rivers passing through spectacular landscapes (Chaperon et al. 1994), volcanic craters lakes (e.g., Lake Tritriva), thermal springs and waterfalls, not to mention the diverse landscapes of rainforest, coral reefs, beaches, and striking mountains and peaks (e.g., Marojejy, Ankaratra, Maromokotra) (Madagascar National Parks 2011)

One of the landforms sculpting the landscape of some protected areas in Madagascar (e.g., Bemahara, Namoroka, Ankarana) is the tsingy, unique and spectacular karst limestone formations which consist of ragged, razor-sharp pinnacles (Rossi 1983, Salomon 2006, veress et al. 2008, 2009). As with typical karst landscapes, the tsingy is associated with caves and underground drainage systems such as streams and rivers. These features are largely the result of surface and subterranean erosion. The ragged razor-sharp karst landscape is formed from the dissolution of the limestone beds near the surface by rainwater as it becomes acidic due to the contact with carbon dioxide in the soil. This acidic rainwater percolates into the ground along fractures in bedrock and dissolves away and enlarges the fractures over time. This process may eventually lead to the development of caves and streams that are characteristics of karst.

\section{VALUES OF GEOSITES AND GEODIVERSITY}

Geosites and geodiversity are certainly valuable, but they have been given minimal consideration. There are several recognisable values of geodiversity (Harmon and Putney 2003, Harmon 2004, Gray 2005, Henriques et al. 2011) but here I only highlight the most important values relevant to the current issues in Madagascar. I do so knowing these values will also clarify the importance of geoconservation in Madagascar.

ECONOMIC VALUES. Geological heritage sites can play an important role in the economic development of local communities through, for example, geological tourism. Madagascar has a large number of fascinating geosites, which can attract many different types of visitors from all socio-cultural backgrounds. Geotourism may play an important role in poverty eradication of an area, and help to build and empower local communities. More interestingly, many potential geosites are themselves the locations of mineral and energy resources. In addition to the oil that has been recently reported in Madagascar (OMNIS 2012), the island is also renowned for its valuable and significant amounts of industrial minerals (quartz, phosphate, gypsum), gemstones (sapphire, ruby, beryl), fossils (ammonites, Majungasaurus), construction minerals/rocks (granites, gabbros, sand, clays), and precious and industrial metallic and non-metallic ore (gold, iron, nickel, copper, aluminium) (Lacroix 1921-1923, Collignon, 1962, Besairie 1964, BGS-USGS-GLW 2008, OMNIS 2012). During the last decades, chromite and graphite are known to be two dominant industrial mineral commodities produced in the country (BGS-USGS-GLW 2008, Yager 2009, 2010, OMNIS, 2012). Today, the nickel-cobalt exploitation in Ambatovy by Sherritt and the ilmenite beach sands in Tolagnaro exploited by Rio Tinto/QIT Madagascar Minerals (QMM) are the largest and the most advanced mineral projects in the country.

AESTHETIC VALUES. The meaning of aesthetic can be broad but here it is used to refer to the beauty of natural landscapes. Several Malagasy tourist attractions are world-class (Christie and Crompton 2003), not only for their biodiversity, but especially for their geodiversity. Tourists visiting the island are drawn to the spectacular beauty of the 
landscape (e.g., tsingy, sandstone canyons of Isalo, volcanic peaks of Tsaratanana), the unique features and stories of lakes (e.g., crater lakes of Tritriva and Andraikiba, and around Itasy volcanic field), hot springs (e.g., Antsirabe and Ranomafana), the mystic and secret of caves (e.g., Ankarana), long and gorgeous beaches and magnificent rivers. While the Malagasy government has promoted and continues to promote tourism, hoping to get more revenue for the country, the importance of geoconservation is always forgotten. Considering that only a few thousand tourists per year visit those geosites, we can only imagine the impact of geotourism on the economy if geoconservation of geosites was truly achieved.

CULTURAL AND ECOLOGICAL VALUES. Madagascar has several spectacular geological and geomorphological features that contribute to the cultural and ecological quality of place, and those have been and could be considered part of its cultural heritage. Good examples are the sacred caves in the north (e.g., Ankarana), the 12 sacred hills in the central highlands, and Isalo National Park in the south. Such valuable areas will not only offer a series of touristic opportunities but also will enhance and deepen the public appreciation of geosites. The exposure to rare minerals, fossils sites, and holy places can be enjoyable and exciting, which may give people insight into the history of the places and thus the science of geology. Some of Madagascar's geological features have even inspired musicians (e.g., the Betsiboka River).

Most of Madagascar's unique landforms and soils support the island's natural ecosystems. Several obvious examples are seen throughout the island such as: (i) in the north, caves in the Ankarana National Park are homes of bats (Cardiff et al. 2009) and cave-living crocodiles (Wilson 1987) - without a safe habitat, these wild animals would be in danger; (ii) the Itremo massif (central Madagascar) is a habitat of small aloe (Aloe parvula) endemic to Madagascar (Cactuspedia 2012), as such the plant relies heavily on the soil and bedrock forming the spectacular quartzite-marble-schist massifs of Itremo (Besairie 1964); (iii) the Tsimanampetsotsa National Park in the south has unique fauna and flora (e.g., endemic carnivore (Galidictis grandidieri), blind fish (Typhleotris madagascariensis) in caves) (Sparks 2011, Wildmadagascar.org 2012,) that need conservation. These examples clearly demonstrate that biological systems (biotic) are inextricably connected to physical systems (abiotic), thus the importance of geoconservation and the ecological values of geodiversity.

INTERNATIONAL SIGNIFICANCE AND EARTH HERITAGE

VALUES. There are many exceptional sites worthy of international recognition in Madagascar (Figure 1). Considering only the tsingy, the Bemaraha, Ankarana and Namoroka protected areas are among the most visited and known by locals.

The largest tsingy is located in Bemaraha in western Madagascar between Morondava and Maintirano. The Tsingy de Bemaraha covers 150,000 hectares of highly karstified limestone formation of the Jurassic age, where the southern part is part of a National Park with public access, while the northern end is a Strict Nature Reserve with no access. The karst is associated with numerous deep canyons and a large river gorge known as Manambolo. The Tsingy de Bemaraha National Park is the first Malagasy site listed as Natural World Heritage and National Cultural Heritage (UNESCO 1990). It also contains vast biodiversity including endemic birds and lemurs (Madagascar National Parks 2011).
The Ankarana National Park is located in the northern part of Madagascar (Figure 1) and it comprises approximately $200 \mathrm{~km}^{2}$ of tsingy (Middleton 2004). The park also includes sacred lakes, canyons, and the largest underground river network in Africa (Madagascar National Parks 2011) with spectacular stalactites and stalagmites, and diverse wildlife including endemic lemurs, bats and crocodiles (Wilson 1987). The Ankarana underground network includes the $>18 \mathrm{~km}$ long Ambatoharanana crocodile cave, the $\sim 11.5 \mathrm{~km}$ long Andrafiabe cave, the $4.5 \mathrm{~km}$ long Lavaka Fanihy bat cave, the approximately $10.4 \mathrm{~km}$ long Antsatrabonko cave and numerous native tombs (Radofilao 1977, Wilson 1990, Middleton 2004). The caves are unique repositories of information for geologists (e.g., speleothems are important for paleoclimate study, clastic sediments are the focus of mineralogical, hydrological and geomorphological studies) and contain a wide range of biodiversity.

The Namoroka National Park $(22,200$ hectares) is located in the northwest of the island, within $180 \mathrm{~km}^{2}$ of Jurassic limestone (Middleton 2004), the same as those seen in the Ankarana. The area also contains a $4.6 \mathrm{~km}$ cave, with natural pools and canyons (Middleton 2004, Madagascar National Parks 2011). Because of their unique wildlife and their bio- and geodiversity values, such parks should be treated as exceptional and international earth heritage sites.

EDUCATION AND TRAINING VALUES. Earth science education is one of the most essential aspects of geosites and significantly contributes to the preservation of the environment and cultural heritage. Geosites not only promote conservation of geological heritages, but also serve as tools for education and training activities at all educational levels in Earth science. As pointed out by Modica (2009), geosites and geoparks provide real-world outdoor classrooms where geology can be explained and communicated in a more interactive way. Rocks, minerals, fossils, landforms and landscapes are all products of the long-term evolution of our planet Earth. Teachers and educators can use geosites for practical demonstration of the fundamental principles of geology and the dynamic evolution over geological time, or the processes of landscape formation and evolution, and also to make students aware of how human occupation and activities can affect the physical environment in general. However, because of the low level of knowledge and awareness of geoconservation in Madagascar, there is a tremendous need for more geoscience education in the country. This is especially true in areas with low levels of school education, as is the case in most regions, bearing in mind that the public's lack of understanding and knowledge about the value and meaning of geodiversity strongly contributes to its destruction. In addition, over the last two decades, many people have depended heavily on natural resources for living, particularly mineral resources. There is clearly a need for large numbers of well-trained geologists to do geological surveys, to locate and extract mineral resources (gemstones, metal ores), oil and gas, water and rocks for industrial purposes which will not only contribute to the economic development of the country, but also to avoid the destructive exploitation of natural resources and the degradation of geosites that sustain the unique biodiversity of Madagascar. There is also a need for large number of geologists to locate aquifers and to study groundwater which plays an important role in all socio-economic development. Furthermore, geologists are an important stepping-stone for 
major engineering projects (e.g., dams and road construction). Thus, geodiversity conservation is undoubtedly vital for promoting education and training, and can be tied into the notion of sustainability. Strengthening of geosciences education is needed to disseminate the values and meaning of geoconservation, and also to produce professional geologists. Increasing knowledge and awareness of geoconservation amongst communities can also be achieved through the uses of available geosites (e.g., organization of guided field trips to selected geosites, TV documentaries and radio programs on tsingy, deltas, fossils, gemstones or other interesting Earth features).

SCIENTIFIC RESEARCH VALUES. The development

of geoparks offers a venue for scientific research. Madagascar's unique tectonic position during the amalgamation and breaking-up of the Gondwana supercontinent (Stern 1994, Shackleton 1996, Collins et al. 2000, Reeves and de Wit 2001, Collins 2006), with its long and complex history of geological evolution (de Wit 2003, Collins 2006), has drawn the attention of many international universities and research institutes, and could promote the scientific education and dissemination of geoscience for the public. An understanding of how different geological features form and what processes shaped the topography and the coastline will enable a large number of the public to have more understanding of the evolution of the earth, and will help them to increase not only their scientific knowledge, but also their awareness of the important values of geological features so that these geological features can be protected.

In this sense, natural rock exposures and landforms become crucial and represent potential tools to gain a better understanding of the geological evolution of the island. Future research could be pursued on, for instance, the history of Madagascar, its geological evolution and the processes that shape the topography and the coastline only when physical evidence are preserved and maintained. Environmental research also depends on the availability of the sites. A good example is the temporal evolution of the Betsiboka delta (Raharimahefa and Kusky 2010), where in the near future researchers will be able to look at the increased amount of sediments in the delta and its relation to natural diversity only if conservation will be undertaken.

INTRINSIC OR EXISTENCE VALUES. Sometimes the

value of geodiversity doesn't have anything to do with human needs or human approval and judgment; it is simply weighted by its natural value (Kiernan 1997, Gray 2005), i.e., as is. Intrinsic value is already a recognized concept in natural conservation (Fox 1990, Nash 1990). A geological feature has intrinsic conservation value because of its type, for example, it is a representative example of a class of landform and should be protected without human scientific justification (Sharples 2002).

\section{THREATS TO EARTH RESOURCES AND GEO- DIVERSITY}

To protect geodiversity, it is important to understand the potential threats (Table 1). Most people would consider that no management and conservation should be taken for Earth features because they are durable and rugged. However, most of the removal and degradation of Earth resources and features are permanent (e.g., coal, oil, minerals, rocks, landscape). If they do recover, it will take thousands, millions, or even billions of years. Accordingly, such resources are in real danger because of human uses and activities. Earth features need to be managed in such a way, at least, that their destruction is minimized.

In Madagascar, the difficulty of exploiting minerals has important economic and environmental impacts. Some mineral resources are starting to be depleted (e.g., graphite, chromite) (Yager 2009, 2010, INSTAT 2011), making it more difficult and expensive to obtain those minerals. Also, everyone should know that every time a mineral is used, that much less remains. For these reasons, conservation of Madagascar's Earth resources is needed, not just by saving these resources, but also by making sure that there is no waste in using them. Geoconservation policy should also include recycling and modernising factories (e.g., recycling of metal cans), as well as improving mining extraction and processing techniques and production.

\section{MOVING FORWARD INTO GEOCONSERVATION}

We are still in the early phases of geoconservation, and the most important steps toward geoconservation are thus listed below; most of them have already been explained by other researchers (cf. Gray 2004, 2005, Burek and Prosser 2008): (i) Public awareness of the importance and value of geology, geoconservation, geodiversity and geosites. This can be done by: (i.1) training the public, especially people who live around and in protected areas, park rangers/technicians, conservation technicians, protected area managers, political leaders, directors of public and private institutions and agencies; (i.2) using mass media: production of TV shows and radio programs dedicated to geological themes, informative web pages, geological booklets, and park guide books; (i.3) raising the importance of geology in school and university curricula, which in part can be enhanced by scientific talks, a variety of publications and magazines, building of educational centres and museums; (i.4) making geological, geomorphological, hydrological, paleontological and pedological resources available (e.g., hard copy maps or through electronic databases). (ii) Inventory and description of Madagascar's geodiversity and geosites, which can be done with local specialists from local universities and collaboration with overseas scientists and academic institutions. (iii) Characterize the values and importance of geosites. (iv) Knowing the threats and make them public, with a commitment to manage and monitor these sites. (v) Establishing geoparks and creating protected areas with the supports of Malagasy authorities (legislation and policy), and local and international non-governmental organizations. This step will need the full approval of the government and their desire to act.

From this step forward, the suggestions will mainly apply to existing protected areas including Strict Nature Reserves, National Parks, special Reserves and private reserves that contain valuable geodiversity and for which geoconservation has not yet been undertaken but where it should start. (i) Valuing and monitoring of geosites by incorporating geology into natural conservation policies at the same level as biodiversity, in other words, influence local plans to support geoconservation. Clear goals should be established for the geoconservation and management of sites. (ii) Periodic training and seminars for park managers as well as regular discussion between geoconservation specialists and the managers, which will increase the awareness of managers. (iii) Encourage public participation, starting from schools and the communities living around the protected areas. (iv) Creating scientific instruments (e.g., data- 
TABLE 1. Examples of principal threats to geodiversity and geosites in Madagascar.

\begin{tabular}{|c|c|c|}
\hline Category & Threats & Examples of principal impacts \\
\hline \multirow[t]{9}{*}{ Natural } & \multirow[t]{5}{*}{ Erosion } & Loss of soil \\
\hline & & Formation of Lavaka \\
\hline & & Coastal changes \\
\hline & & Silting and filling of lakes, delta and lowland rivers \\
\hline & & Loss of geological exposure \\
\hline & \multirow[t]{4}{*}{ Excess Rainfall } & Flood \\
\hline & & Slope instability \\
\hline & & Slumping of unconsolidated sediments \\
\hline & & Erosion of sandy shorelines \\
\hline \multirow[t]{35}{*}{ Human activities } & \multirow{9}{*}{$\begin{array}{l}\text { Mining (small and large scale } \\
\text { industrial and gemstones } \\
\text { extraction, building stones } \\
\text { quarries) }\end{array}$} & Destruction of landscape \\
\hline & & Large-scale removal of soil \\
\hline & & Water and air pollution \\
\hline & & Depletion of mineral resources \\
\hline & & Removal of geological specimens \\
\hline & & Flooding and open holes after mines closure \\
\hline & & Loss of geological exposures \\
\hline & & Damage to geomorphological features and disturbance of natural processes \\
\hline & & Face stability problems \\
\hline & \multirow[t]{12}{*}{ Urban activities } & Land conversion \\
\hline & & Change of topography and visibility \\
\hline & & Loss and damage of important rocks, minerals and fossils \\
\hline & & Waste disposal and Landfill issues \\
\hline & & Damage to groundwater and surface water \\
\hline & & Sewage waste affecting pods, rivers and streams \\
\hline & & Noise and Air pollution \\
\hline & & Loss of geological exposure \\
\hline & & Filling of mangrove, paddy field, streams and swamps \\
\hline & & Re-profiling and leveling affecting landscape (cause interruption of natural processes) \\
\hline & & Dredging of rivers, paddy field and swamps. \\
\hline & & $\begin{array}{l}\text { The removal of irreplaceable features such as caves, landforms or finite deposits of fossils or } \\
\text { minerals. }\end{array}$ \\
\hline & \multirow[t]{6}{*}{ Tourism and visitor } & Littering \\
\hline & & Trail degradation \\
\hline & & Soil compaction and degradation \\
\hline & & Loss of vegetation cover \\
\hline & & Episodic sedimentation in lowland river systems \\
\hline & & Inappropriate removal of geological specimens \\
\hline & \multirow[t]{4}{*}{ Agriculture } & Land conversion \\
\hline & & Loss of soil \\
\hline & & Soil contamination \\
\hline & & Inappropriate burning increases erosional processes \\
\hline & \multirow[t]{2}{*}{ Deforestation } & Degradation of landscape and landform \\
\hline & & Temporary increases in sediment yield and run-off \\
\hline & \multirow[t]{2}{*}{ Lack of public understanding } & Inappropriate management causes destruction of geological features \\
\hline & & Graffiti and spray-painted mask potential geological features \\
\hline
\end{tabular}

bases, maps, manuals, survey materials) to support a sustainable management of the geological or Earth resources. (v) Find funds for geoconservation and establish clear strategies to build human and financial resources for the planning process. One way is seeking integration into the African Geoparks Network and Global Geoparks Network. (vi) Integrating geoconservation with land-use planning and land management, e.g., retaining the integrity of geodiversity in geosites and restoring them authenti- cally where possible. (vii) Develop a nature conservation initiative showing the integration of biodiversity and geodiversity.

\section{BARRIERS TO GEOCONSERVATION}

Despite all of the progress Madagascar has made since the introduction of biodiversity conservation in the 1980s and the efforts of conservationists, periodic political crises and instability are the main barriers for any conservation efforts in Madagascar. In 
addition to deforestation, biodiversity conservation is now facing the most difficult challenges with increasing illicit logging and exportation of rosewood (Schuurman and Lowry 2009, Butler 2010, Innes 2010, Randriamalala and Liu 2010, Randriamalala et al. 2011) as well as the illegal exportation of endangered tortoises (Guanqun 2011) and hunting lemurs for food (Reardon 2011). The current political unrest masks the conservation effort and has raised the number of Malagasy living in poverty to $77 \%$ of the population (Taratra 2012).

From the geoconservation perspective, since very little has been done, no significant damage has been reported except the intensive illegal exploitation of gems (Andrianandraina 2012, Niaina 2012). The current crisis will, of course, disturb the implementation of geoconservation. As such, the inventory of geosites and the integration of geoconservation within state policies on nature conservation would be hampered until the establishment of a stable government; however, geoconservation can be initiated by using mass media to educate the public about the importance and the value of geoconservation. Concurrently, the Ministry of Education should incorporate geoconservation into school and university curricula. Geological surveys should work on the inventory and description of Madagascar's geodiversity and geosites. Conservation and development depend on everyone's participation; as such the public's level of education is the most important factor.

\section{CONCLUSION}

Madagascar's geodiversity is threatened by many potentially damaging human activities enhanced by poverty, irresponsible management and unawareness of the public and local authorities. The use of natural resources subsequently leads to the transformation of ecological and geological habitats as well as the loss of flora and fauna. Geoconservation plays a key role in nature conservation and in sustainable development. Currently, it is only in its early stages; however, because of the several threats to Madagascar's geodiversity, conservation action should be taken. One of the most important steps is to educate the public and local authorities. Public understanding of basic science is a must; as such, education plays a vital role in geoconservation. Geosites should be protected under national conservation legislation; however it does not guarantee conservation due to political instability, infringement of regulations, and lack of funding.

\section{ACKNOWLEDGMENTS}

I would like to thank the editors of Madagascar Conservation and Development for the invitation to write this article, and for their great patience in waiting for its delivery as well as for their helpful comments and suggestions. I also thank the three anonymous reviewers for thoroughly reading the paper and for providing constructive reviews of the manuscript. I gratefully acknowledge fruitful discussions with Davida S. Rakotoarivelo.

\section{REFERENCES}

Andrianandraina, H. F. 2012. Ambatondrazaka: Le traffic de saphir reprend. <http://www.lexpressmada.com/ambatondrazaka-madagascar/38162le-trafic-de-saphir-reprend.html> accessed 31 October 2012.

Arthaud, F., Grillot, J-C. \& Raunet, M. 1990. La tectonique cassante à Madagascar: son incidence sur la géomorphologie et sur les écoulements. Canadian Journal of Earth Sciences 27, 10: 1394-1407. (doi:10.1139/e90-149)
BPGRM. 2005. Base de Données Pour la Gouvernance des Ressources Minérales. Service Géologique Ministère de l'Énergie et des Mines, Antananarivo.

Behier, J. 1960. Travaux minéralogiques. In: Rapport Annuel du Service Géologique pour 1960. H. Besairie (ed.), pp 186-187, Service Géologique de la République Malgache, Antananarivo.

Besairie, H. 1964. Carte Géologique de Madagascar 1/1,000,000. Service Géologique de Madagascar, Antananarivo.

Besairie, H. 1968. Description du massif ancien de Madagascar. I. Centre Nord et Centre Nord-Est. Document Bureau Géologique Madagascar. Service Géologique de Madagascar, Antananarivo.

Boule, M. \& Thévenin, A. 1906. Paléontologie de Madagascar. I. Fossiles de la côte orientale. Annales de Paléontologie 1, 1-2: 43-59.

BGS-USGS-GLW (British Geological Survey-United States Geological SurveyGLW Conseil). 2008. Révision de la Cartographie Géologique et Minière des Zones Nord et Centre de Madagascar. Ministère de l'Énergie et des Mines, Antananarivo.

BTI (Bertelsmann Stiftung's Transformation Index). 2012. Madagascar Country Report. <http:/www.bti-project.org> accessed 15 October 2012.

Burek, C. V. and Prosser, C. D. 2008. The history of geoconservation: an introduction. Geological Society, London, Special Publication 300: 1-5. (doi:10.1144/SP300.1)

Butler, R. A. 2010. Satellites being used to track illegal logging, rosewood trafficking in Madagascar. <http://news.mongabay.com/2010/0128madagascar.html> accessed 12 November 2011.

Cactuspedia, 2012. Aloe parvula. <http://www.cactus-art.biz/schede/ALOE/ Aloe_parvula/Aloe_parvula/Aloe_parvula.htm > accessed 12 October 2012

Cardiff, S. G., Ratrimomanarivo, F. H., Rembert, G. and Goodman, S. M. 2009. Hunting, disturbance and roost persistence of bats in caves at Ankarana, northern Madagascar. African Journal of Ecology 47: 640-649. (doi:10.1111/j.1365-2028.2008.01015.x)

Chaperon, P., Danloux, J. \& Ferry, L. 1994. Fleuves et rivières de Madagascar. Centre National de Recherche sur l'Environnement, Antananarivo, Office de la Recherche Scientifique et Technique Outre-Mer, Paris.

Christie, I. T. and Crompton, E. D. 2003. Republic of Madagascar: Tourism Sector Study. Africa Region Working Paper Series No. 63 (E). <http:// www.worldbank.org/afr/wps/wp63.pdf> accessed 5 November 2011.

Collignon, M. 1962. Atlas des Fossiles Caractéristiques de Madagascar (Berriassian, Valanginien, Hauterivien, Barremien). Service Géologique de la République Malgache, Antananarivo.

Collins, A. S. 2006. Madagascar and the amalgamation of central Gondwana, Gondwana Research 9: 3-16. (doi:10.1016/j.gr.2005.10.001)

Collins, A. S., Razakamanana, T. and Windley, B. F. 2000. Neoproterozoic crustal-scale extensional detachment in Central Madagascar: implications for extensional collapse of the East African Orogen. Geological Magazine 137: 39-51.

de Wit, M. J. 2003. Madagascar: heads it's a continent, tails it's an island. Annual Review of Earth and Planetary Sciences 31: 213-248. (doi:10.1146/annurev.earth.31.100901.141337)

Dixon, G. 1995. Aspects of Geoconservation in Tasmania: A Preliminary Review of Significant Earth Features. Report to the Australian Heritage Commission, Occasional Paper no. 32. Parks and Wildlife Service, Hobart.

Duflos, J. 1966: Bilan des explorations biospéléologiques pour 1965. Revue de Géographie de Madagascar 9: 235-252.

Foiben-Taosaritanin'i Madagascar (FTM). 1998. BD500. Les bases des données vecteur à 1/500 000. FTM, Madagascar.

Foiben-Taosaritanin'i Madagascar (FTM). 2001. BD200. Les bases des données vecteur à 1/200 000. FTM, Madagascar.

Fox, W. 1990. Toward a Transpersonal Ecology - Developing New Foundations for Environmentalism. Shambala Publications, Inc., Boston.

Ganzhorn, J. U., Lowry II, P. P., Schatz, G. E. and Sommer, S. 2001. The biodiversity of Madagascar: one of the world's hottest hotspots on its way out. Oryx 35: 346-348. (doi:10.1046/j.1365-3008.2001.00201.x)

Goodman, S. M. and Benstead, J. P. (eds.) 2003. The Natural History of Madagascar. University of Chicago Press, Chicago. 
Gray, M. 2004. Geodiversity: Valuing and Conserving Abiotic Nature. John Wiley and Sons, Chichester.

Gray, M. 2005. Geodiversity and geoconservation: what, why and how? The George Wright Forum 22, 3: 4-12.

Guanqun, W. 2011. Illegal export of species on rise amid Madagascar crisis <http://news.xinhuanet.com/english2010/world/201105/03/C_13857396.htm> accessed 10 November 2011.

Guilcher, A. 1965. La géomorphologie de lsextrême sud de Madagascar, d'après René Battistini. Annales de Géographie 74, 404: 491-495.

Harmon, D. and Putney, A. D. 2003. The Full Value of Parks: From Economics to the Intangible. Rowman \& Littlefield, Lanham.

Harmon, D. 2004. Intangible values of protected areas: what are they? Why do they matter? The George Wright Forum 21, 2: 9-22.

Henriques, M. H., dos Reis, R. P., Brilha, J. and Mota, T., 2011. Geoconservation as an emerging geoscience. Geoheritage 3: 117-128. (doi:10.1007/s12371-011-0039-8)

Hogarth, D. D. 1977. Classification and nomenclature of the pyrochlore group. American Mineralogist 62: 403-410

Innes, J. L. 2010. Madagascar rosewood, illegal logging and the tropical timber trade. Madagascar Conservation \& Development 5, 1: 6-10.

INSTAT (Institut National de la Statistique de Madagascar). 2011. <http:// www.instat.mg> accessed 14 November 2011.

Jenkins, M. D. 1990. Madagascar: Profil de l'Environnement. IUCN, UNEP and WWF.

Kiernan, K. 1997. Landform classification for geoconservation. In: Pattern and Process: Towards a Regional Approach to National Estate Assessment of Geodiversity. R. Eberhard (ed.), pp 21-34. Environment Australia, Canberra.

Lacroix, A. 1921-1923. Minéralogie de Madagascar. Challamel, Paris

Legge, P. and King, R. 1992. Geological Society of Australia Inc Policy on Geological Heritage in Australia. The Australian Geologist 85: 18-19.

Madagascar National Parks. 2011. <http://www.parcs-madagascar.com> accessed 12 December 2011.

Middleton, G. 2004. Madagascar. In: Encyclopedia of Caves and Karst Science, J. Gunn (ed.), pp 1085-1100. Routledge, London.

Mittermeier, R. A., Langrand, O., Lowry II, P. P., Schatz, G. G., Gerlach, J., Goodman, S., Steininger, M., Hawkins, F., Raminosoa, N., Ramilijaona, O., Andriamaro, L., Randrianasolo, H., Rabarison, H. and Rakotobe, Z. L. 2004. Madagascar and the Indian Ocean Islands. In: Hotspots Revisited: Earth's Biologically Richest and Most Threatened Terrestria Ecoregions, R. A. Mittermeier, N. Myers, P. R. Gil and C. G. Mittermeier (eds.), pp 138-144. CEMEX, Mexico City.

Modica, R. 2009. European and Global Geoparks Network (EGN and GGN): Protection of geological heritage, opportunity of local development and collaboration among territories. Geologia USP Special Publication 5: $17-26$.

Myers, N., Mittermeier, R. A., Mittermeier, C. G., de Fonseca, G. A. B. and Kent, J. 2000. Biodiversity hotspots for conservation priorities. Nature 403: 853-858. (doi:10.1038/35002501)

Nash, R. F. 1990. The Rights of Nature - A History of Environmental Ethics; Primavera Press, Leichhart, New South Wales.

Niaina, N. 2012. Corridor Ankeniheny-Zahamena : 30.000 exploitants illicites menacent la conservation. NewsMada.< http://www.newsmada. com/corridor-ankeniheny-zahamena-30-000-exploitants-illicitesmenacent-la-conservation/> accessed 13 May 2012.

OMNIS (Office des Mines Nationales et des Industries Stratégiques. 2012. <http://www.omnis.mg> accessed 20 March 2012

Osborne, R. A. L., 2000. Geodiversity: "green" geology in action. Proceedings of the Linnean Society of New South Wales 122: 149-173.

Peters, S. G., Bawiec, W. J. and Sutphin, D. M. 2003. Pre-assessment of Madagascar's Undiscovered Non-Fuel Mineral Resources. US Geological Survey.

ProGEO, 2011. Conserving our Shared Geoheritage - a Protocol on Geoconservation Principles, Sustainable Site Use, Management, Fieldwork, Fossil and Mineral Collecting. <http://www.progeo.se/ progeo-protocol-definitions-20110915.pdf> accessed 3 January 2012

Prosser, C. 2002. Terminology: speaking the same language. Earth Heritage 18: 24-25.
Radofilao, J. 1977. Bilan des explorations spéléologiques dans I'Ankarana. Annales de I'Université de Madagascar: série Sciences de la Nature et Mathématiques 14: 195-204.

Raharimahefa, T. and Kusky. T. M. 2010. Environmental monitoring of Bombetoka Bay and the Betsiboka estuary, Madagascar, using multitemporal satellite data. Journal of Earth Sciences 21, 2: 210-226. (doi:10.1007/s12583-010-0019-y)

Randriamalala, H. and Liu, Z. 2010. Rosewood of Madagascar: between democracy and conservation. Madagascar Conservation \& Development 5, 1: 11-22.

Rakotondrazafy, A. F. M., Giuliani, G., Ohnenstetter, D., Fallick, A. E., Rakotosamizanany, S., Andriamamonjy, A., Ralantoarison, T., Razanatseheno, M., Offant, Y., Garnier, V., Maluski, H., Dunaigre, C., Schwarz, D. and Ratrimo, V. 2008. Gem corundum deposits of Madagascar: a review. Ore Geology Reviews 34, 1-2: 134-154. (doi:10.1016/j.oregeorev.2007.05.001)

Randriamalala, H., Rasarely, E., Ratsimbazafy, J., Brizzi, A., Ballet, J. Razakamanarina, N., Ratsifandrihamanana, N., Schuurman, D. 2011. Stocks de bois précieux de Madagascar - quelle voie emprunter? Madagascar Conservation \& Development 6, 1: 88-96. (doi:10.4314/ mcd.v6i2.8)

Ranorosoa, N., Fontan, F. and Fransolet, A.-M. 1989. Rediscovery of manandonite in the Sahatany Valley, Madagascar. European Journal of Mineralogy 1: 633-638.

Reardon, S. 2011. Falling Taboos Put Lemurs on the Menu in Madagascar <http://news.sciencemag.org/sciencenow/2011/12/falling-taboos-putlemurs-on-the.html> accessed 20 December 2011

Reeves, C. V. and de Wit, M. J. 2001. Making ends meet in Gondwana: retracing the transforms of Indian Ocean and reconnecting continental shear zones. Terra Nova 12: 272-280. (doi:10.1046/j.13653121.2000.00309.x)

Rogers, J. J. W. and Santosh, M. 2002. Configuration of Columbia, a Mesoproterozoic supercontinent. Gondwana Research 5: 5-22. (doi:10.1016/S1342-937X(05)70883-2)

Rogers, H. M., Glew, L., Honzak, M. and Hudson, M. 2010. Prioritizing key biodiversity areas in Madagascar by including data on human pressure and ecosystem services. Landscape and Urban Planning 96: 48-56. (doi:10.1016/j.landurbplan.2010.02.002)

Rossi, G. 1983. Karst and structure in tropical areas: the Malagasy example. In: New Directions in Karst: Proceedings of the Anglo-French Karst Symposium, September 1983. K. Paterson and M. M. Sweeting (eds.), pp 383-407. Geo Books, Norwich.

Salomon, J. N. 2006. Les tsingy et leur genèse. Spelunca 103: 45-50.

Schuurman, D. and Lowry II, P. P. 2009. The Madagascar rosewood massacre. Madagascar Conservation \& Development 4, 2: 98-102.

Schwarz, D. and Henn, U. 1992. Emeralds from Madagascar. Journal of Gemmology 23, 3: 140-149.

Semeniuk, V. 1997. The linkage between biodiversity and geodiversity. In: Pattern \& Processes: Towards a Regional Approach to National Estate Assessment of Geodiversity. R Eberhard (ed.), pp 51-58. Technical Series No. 2, Australian Heritage Commission \& Environment Forest Taskforce, Environment Australia, Canberra.

Shackleton, R. M., 1996. The final collision zone between east and west Gondwana: where is it? Journal of African Earth Sciences, 23: 271-287. (doi:10.1016/S0899-5362(97)00002-X)

Sharples, C. 1993. A methodology for the identification of significant landforms and geological sites for geoconservation purposes. Report to Forestry Commission Tasmania, Hobart, Tasmania.

Sharples, C. 1995. Geoconservation in forest management - principles and procedures. Tasforests 7: 37-50.

Sharples, C. 2002. Concepts and Principles of Geoconservation. Tasmanian Parks \& Wildlife Service, Hobart.

Sparks, J. S. 2011. The cave fish of Madagascar. <http://scientistatwork blogs.nytimes.com/2011/06/13/the-cave-fishes-of-madagascar/> accessed 12 November 2011.

Stern, R. J. 1994. Arc assembly and continental collision in the Neoproterozoic East Africa Orogen: implications for the consolidation of Gondwanaland. Annual Review of Earth and Planetary Sciences 22: 319-351. (doi:10.1146/annurev.ea.22.050194.001535) 
Système des Aires Protégées de Madagascar (SAPM). 2011. Système des Aires Protégées et KoloAla. <http://atlas.rebioma.net/> accessed 5 November 2011.

Taratra. 2012. Banky Iraisam-pirenena : mihamahantra ny Malagasy tato anatin'ny 20 taona. NewsMada <http://www.newsmada.com/ banky-iraisam-pirenena-mihamahantra-ny-malagasy-tato-anatinny20-taona/> accessed 30 June 2012.

UNESCO 1990. Tsingy de Bemaraha Strict Nature Reserve <http://whc unesco.org/en/list/494> accessed 13 November 2011

Veress, M., Lóczy, D., Zentai, Z., Tóth, G. and Schläffer, R. 2008. The origin of the Bemaraha tsingy (Madagascar). International Journal of Speleology 37, 2: 131-142

Veress, M., Tóth, G., Zentai, Z. and Schläffer R. 2009. The Ankarana tsingy and its development. Carpathian Journal of Earth and Environmental Sciences 4, 1: 95-108.

Vogt, J. 1965. Notes de géomorphologie Malgache (première partie). Revue de Géographie de Madagascar 7:63-91.

Wildmadagascar.org. 2012. Tsimanampetsotsa. <http://www.wildmadagascar.org/conservation/parks/Tsimanampetsotsa.html> accessed 2 January 2012.

Wilson, J. M. 1987. The crocodile caves of Ankarana, Madagascar. Oryx, 21 $43-47$.

Wilson, J. H. 1990. Lemurs of the Lost World: Exploring the Forests and Crocodile Caves of Madagascar. Impact, London.

World Commission on Environment and Development, 1987. Our Common Future. Oxford University Press, Oxford.

Yager, T. R. 2009. The mineral industry of Madagascar. U.S. Geological Survey Minerals Yearbook 26: 1-6.

Yager, T.R. 2010. The mineral industry of Madagascar. U.S. Geological Survey Minerals Yearbook 26: 1-6.

Yatheesh, V., Bhattacharya, G. C. and Mahender, K. 2006. The terrace like feature in the mid-continental slope region off Trivandrum and a plausible model for India-Madagascar juxtaposition in immediate pre-drift scenario. Gondwana Research 10: 179-185. (doi:10.1016/j. gr.2005.11.021) 